\title{
Analysis of Asymmetric Cell Division Using Human Neuroblastoma Cell Lines as a Model System
}

\author{
Hideki Izumi $^{1, * \mathbb{D}}$, Yasuhiko Kaneko ${ }^{2}$ and Akira Nakagawara ${ }^{3}$ \\ 1 Laboratory of Molecular Medicine, Saga Medical Center KOSEIKAN, Life Sciences Institute, \\ Saga 840-8571, Japan \\ 2 Saitama Cancer Center, Research Institute for Clinical Oncology, Saitama 362-0806, Japan; \\ kaneko@saitama-pho.jp \\ 3 Saga HIMAT, Tosu 841-0071, Japan; nakagawara.akira@gmail.com \\ * Correspondence: izumi-hideki@koseikan.jp
}

Citation: Izumi, H.; Kaneko, Y.; Nakagawara, A. Analysis of

Asymmetric Cell Division Using Human Neuroblastoma Cell Lines as a Model System. Symmetry 2021, 13, 1907. https://doi.org/10.3390/ sym13101907

Academic Editors: Mihail E. Hinescu and Laura Cristina Ceafalan

Received: 2 August 2021

Accepted: 6 October 2021

Published: 11 October 2021

Publisher's Note: MDPI stays neutral with regard to jurisdictional claims in published maps and institutional affiliations.

Copyright: (C) 2021 by the authors Licensee MDPI, Basel, Switzerland. This article is an open access article distributed under the terms and conditions of the Creative Commons Attribution (CC BY) license (https:// creativecommons.org/licenses/by/ $4.0 /)$.

\begin{abstract}
Neuroblastoma is one of the most common childhood solid tumors and develops from neural stem cells that normally comprise the embryonic structure termed the neural crest. Human neuroblastoma cell lines have special properties as they exhibit cell growth and are induced to become mature neurons by drugs such as retinoid. Therefore, we examined asymmetric cell division (ACD) using human neuroblastoma cells as an ACD model, and confirmed that ACD in human cancer cells is evolutionally conserved. Furthermore, we demonstrated that MYCN is involved in cell division fate. We introduce the brief history of ACD study using neuroblastoma cell lines and discuss why human neuroblastoma cells are an ideal model system for clarifying the mechanism of ACD.
\end{abstract}

Keywords: neuroblastoma; asymmetric cell division; centrosome; MYCN; TRIM32

\section{Introduction}

Neuroblastoma is one of the most typical solid tumors among childhood cancers and exhibits a wide clinical range [1-3]. Patients can be broadly divided into three patterns (lowrisk, medium-risk, and high-risk groups) from a biological and clinical point of view [1-3]. Although minimum treatment may be sufficient for low-risk patients, high risk patents have poor results in spite of aggressive treatment. Among several biological features, amplification of the MYCN gene is known to correlate with its prognosis and malignancy. In fact, approximately $20 \%$ of neuroblastomas have MYCN gene amplification. Recent studies showed that MYCN not only exhibits oncogenic activity, but also plays a role in the self-renewal of normal neural stem cells and progenitor cells [4-7].

Neuroblastoma is believed to be derived from the multipotent neural crest cells that make up the structure of the embryo [8]. The neural crest is composed of a cell population that produce cell lineage such as Schwann cell, melanocyte, smooth muscle, peripheral neurons, and glia [8]. Therefore, neuroblastoma cells are suspected to be similar in nature to cancer stem cells due to their pluripotent function.

Cancer stem cells are thought to exhibit asymmetric cell division (ACD), which results in tumor cell heterogeneity $[9,10]$. ACD is a originate physiological process to maintain the stem cell pool and differentiated cell pool through a single cell division. Recent studies showed that the imbalance between self-renewal and differentiation causes the appearance of abnormal stem cells, leading to tumorigenesis in the Drosophila neuroblast population [11-13]. Thus, ACD is a strategy for producing many cancer stem cells and differentiated cancer cells. We used a series of cultured human neuroblastoma cells as a model system to investigate the underlying mechanism of ACD [14-17]. 


\section{Discovery of ACD in Human Neuroblastoma Cells}

ACD studies were originally demonstrated using model organisms, such as nematode embryos [18,19], Drosophila neuroblasts [20], and Drosophila male germ stem cells [21]. These genetic studies showed that the mechanism of ACD is highly conserved. Thereafter, evidence supporting asymmetric cell division in mammalian stem cells, such as muscle [22], skin [23], gut [24], mammary glands [25], the hematopoietic system [26], and developing mouse brain $[27,28]$, was reported.

As mentioned above, human neuroblastoma cell lines have special properties as they exhibit cell growth and are induced to become mature neurons by drugs such as retinoid [29]. In addition, neuroblastoma is a common childhood cancer that may develop at the fetal development stage when a large number of stem cells display ACD [17]. Therefore, we investigate ACD using human neuroblastoma cells as a model [14]. As a result, although the cell lines with MYCN amplification exhibited symmetric cell division (self-renewal division), the cell lines without $M Y C N$ amplification exhibited ACD (Figure 1). In addition, comparison of ACD studies using these organisms and model systems demonstrated that ACD in neuroblastoma cells is evolutionarily conserved [14].

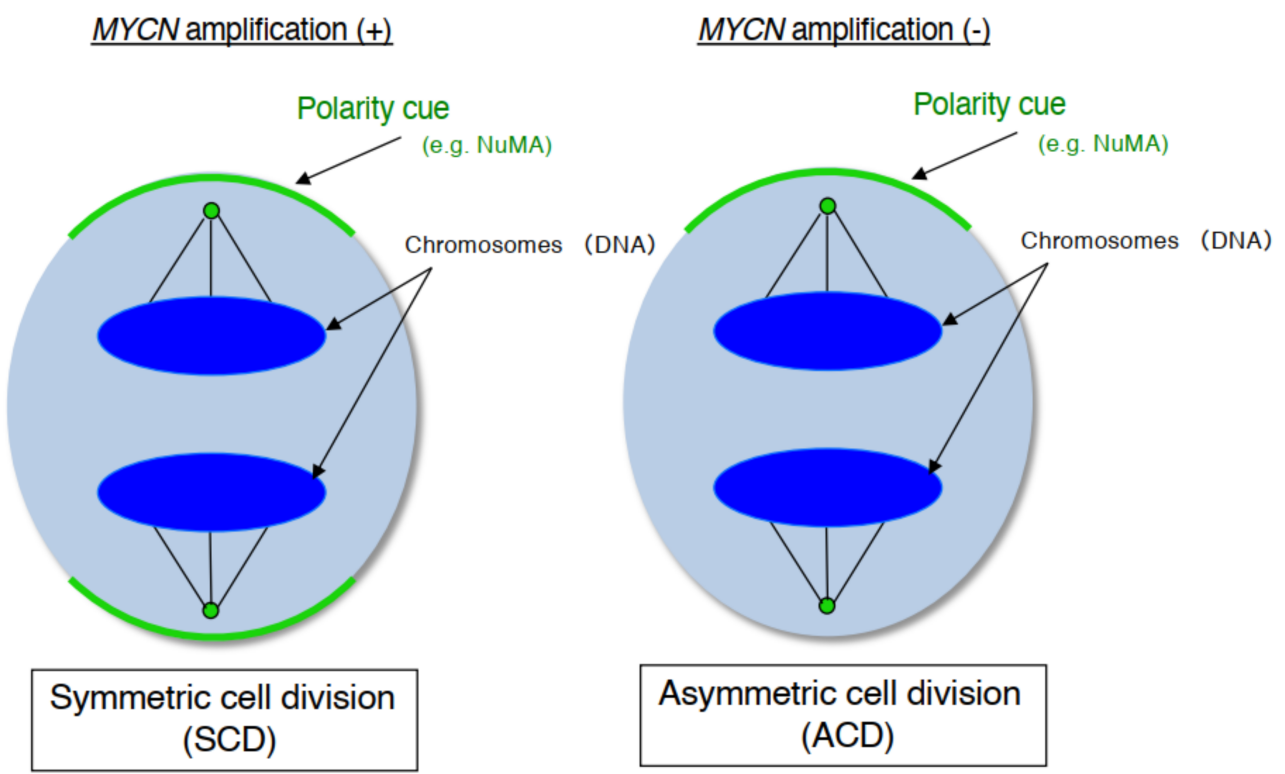

Figure 1. Detection of NuMA-based asymmetric cell division in human neuroblastoma cells.

During late mitosis (anaphase), spindle pole-localized NuMA also localizes to the cell cortex as a polarity cue, and the cell cortex localized-NuMA ensures proper polarity division. Neuroblastoma cells with MYCN amplification exhibit symmetric NuMA cortexbased cell division, whereas those without MYCN amplification exhibit asymmetric NuMA cortex-based cell division (the ACD ratio is approximately $20 \%$ ).

\section{MYCN Regulates Cell Division Fate}

MYCN is a typical transcriptional factor that belongs to the MYC family (c-MYC, L-MYC) [30]. As mentioned above, recent studies have reported that MYCN not only exhibits oncogenic activity, but also plays a central role in the self-renewal of normal neural stem and progenitor cells [31].

In our experiments, the gene expression level of $M Y C N$ influenced the control of cell division fate. The overexpression of $M Y C N$ induced symmetric cell division (SCD) (selfrenewal division), whereas decreased expression of $M Y C N$ caused ACD [14]. Moreover, when its leucine zipper domain was deleted, the MYCN mutant no longer induced selfrenewal division. This suggested that the transcriptional activity of MYCN is necessary for inducing SCD in human neuroblastoma cells [14]. Although the specific transcriptional tar- 
get(s) of MYCN currently remain unclear except for the high mobility group A1 (HMGA1) oncogene [32], several molecular pathways have been identified in MYCN-mediated cell division fate (Figure 2) [17].

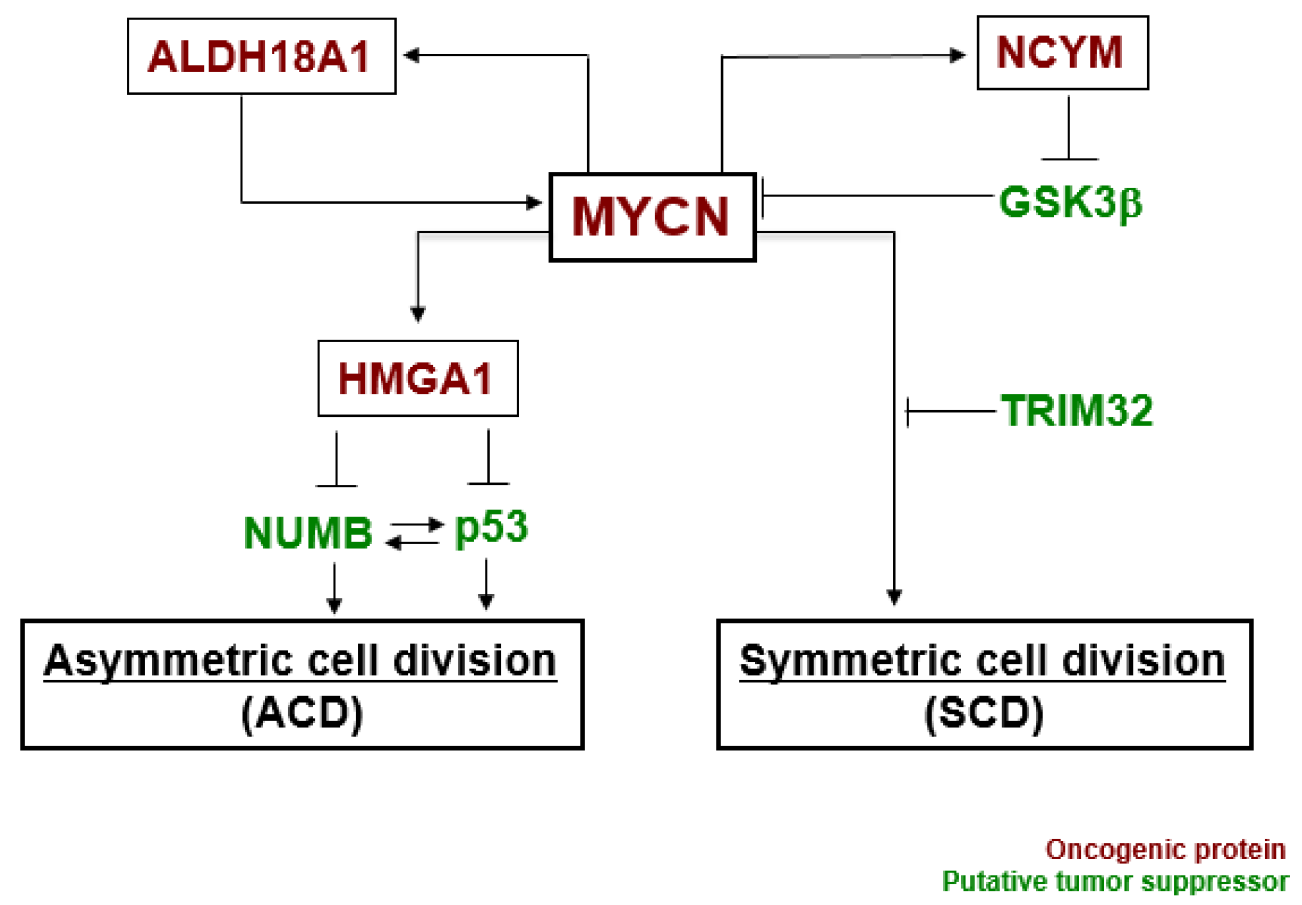

Figure 2. The pathways of MYCN-mediated cell division fate.

MYCN and ALDH18A1 form a positive feedback loop for their transcriptional expression [33]. This positive feedback loop effectively induces symmetric cell division (SCD). NCYM inhibits GSK3 $\beta$-mediated phosphorylation of MYCN, resulting in induction of SCD [34,35]. HMGA1 is a transcriptional target of MYCN [32]. HMGA1 inhibits the expression of NUMB [36] and p53 [37]. NUMB and p53 induce asymmetric cell division (ACD) $[25,38]$. Lastly, TRIM32 facilitates proteasomal degradation of MYCN to induce asymmetric cell division (ACD) [15]. Thus, MYCN-dependent tumor cells exhibit symmetric cell division (SCD) and the degradation of MYCN causes asymmetric cell division (ACD).

\section{Induction of ACD in Human Neuroblastoma Cells}

Based on the results of above previous studies, we searched for a molecule that degrades the MYCN protein and induces asymmetric division, focusing on TRIM32 (Tripartite motif-containing 32) by analogy. Previous studies reported that TRIM32, an ortholog of Drosophila melanogaster, Brat, which controls ACD as a determinant of neuron, suppresses Drosophila MYC (dMYC) function in the neuroblasts of flies [39]. Moreover, mouse TRIM32 was reported to have ubiquitin ligase activity, and facilitated the degradation of the c-MYC oncoprotein during neurogenesis [40]. In neuroblastoma cells, TRIM32 associated with MYCN at the spindle pole during mitosis and facilitated the degradation of MYCN protein as an ubiquitin ligase [15]. In addition, when TRIM32 was overexpressed, ACD was detected in human neuroblastoma cells, as expected (Figure 3) [15]. 
A

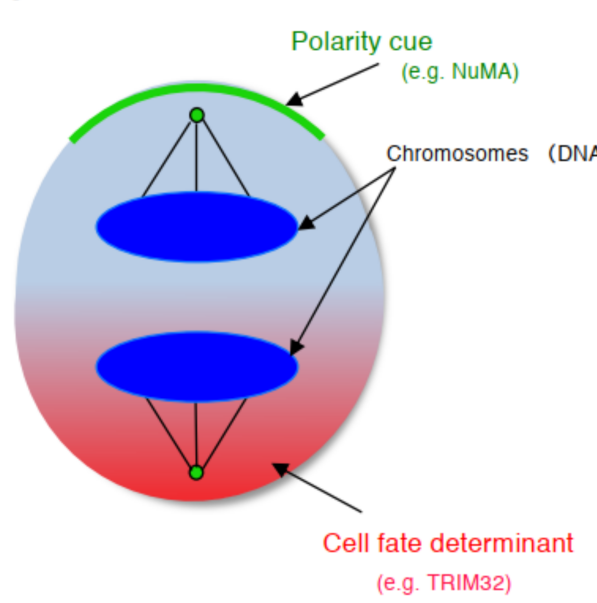

B
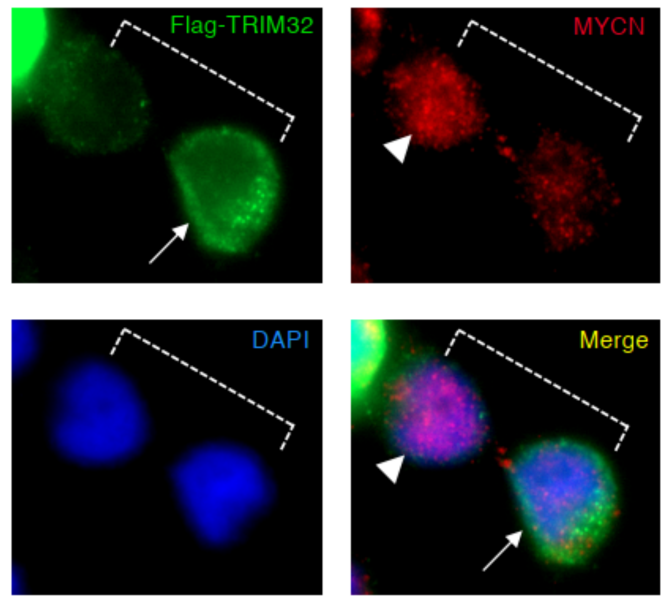

Figure 3. Detection of NuMA/TRIM32-based asymmetric cell division in human neuroblastoma cells (A) Overexpression of TRIM32 can induce asymmetric cell division. During late mitosis (anaphase), NuMA leads to complete polarity cell division as a cell polarity cue, whereas TRIM32 functions in asymmetric cell division as a cell fate determinant. (B) Representative image of asymmetric cell division in SK-N-DZ neuroblastoma cells with MYCN amplification transfected with the FlagTRIM32 expression vector. TRIM32 encodes a ubiquitin ligase for MYCN degradation.

\section{Centrosome Inheritance in ACD}

During the process of $A C D$, there is some controversy regarding the patterns of centrosome inheritance, as different results have been reported among studies using different model systems [41]. Recent results are summarized in Table 1. In the G1 phase of the cell cycle, the centrosome consists of one mother centriole and one daughter centriole. During the replication of the centriole, there are three generations of centrioles: an older mother, a younger mother, and two new daughter centrioles. The centrosome with the old mother's centriole is termed the mother centrosome. In the case of male germline stem cells of Drosophila melanogaster, [21], mouse neural progenitor cells [28], and mouse ES cells [42], the mother centrosome remains in the stem cell and the daughter centrosome is inherited by the daughter cell that has differentiation potential. On the other hand, in the case of Drosophila melanogaster neuroblasts [43], female germline stem cells [44] and human neuroblastoma cells [14], the mother centrosome does not stay in the daughter cells with self-renewal ability, but is inherited by those with differentiation potential.

Table 1. A list of asymmetric centrosome segregation in asymmetric cell division.

\begin{tabular}{c|c|c}
\hline Model & $\begin{array}{c}\text { Pattern of Centrosome } \\
\text { Inheritance } \\
\text { Drosophila male germ stem cells }\end{array}$ & $\begin{array}{c}\text { Stem cells inherit the } \\
\text { mother centrosome }\end{array}$ \\
\hline Drosophila female germ stem cells & $\begin{array}{c}\text { Stem cells inherit the } \\
\text { daughter centrosome }\end{array}$ & {$[21]$} \\
\hline Drosophila neuroblasts & $\begin{array}{c}\text { Stem cells inherit the } \\
\text { daughter centrosome }\end{array}$ & {$[43]$} \\
\hline Mouse neural progenitors & $\begin{array}{c}\text { Stem cells inherit the } \\
\text { mother centrosome }\end{array}$ \\
\hline Mouse ES cells & $\begin{array}{c}\text { Stem cells inherit the } \\
\text { mother centrosome }\end{array}$ & {$[42]$} \\
\hline Human neuroblastoma cells & $\begin{array}{c}\text { NuMA+ cells inherit the } \\
\text { daughter centrosome }\end{array}$ \\
\hline
\end{tabular}

Of note, in human glioblastoma cells, the result was opposite when compared with that from neuroblastoma cells (Koguchi and Izumi, unpublished work). Glioblastoma originates from the central nervous system, whereas neuroblastoma is from the peripheral 
nervous system. Therefore, the mechanism of centrosome inheritance in stem cells may differ between the central and peripheral nervous systems. Alternatively, "centrosome inheritance instability" may be characteristic of cancer (stem) cells.

\section{Conclusions}

Why do cultured neuroblastoma cells display ACD? As mentioned above, many cultured neuroblastoma cells exhibit a special ability to proliferate and differentiate. Previous studies have shown that human neuroblastoma cell lines are classified into three different cell phenotypes with different potencies: neuroblastoma type (N-type), substrate adherent type (S-type), and intermediate type (I-type) [8]. Based on its morphological, biochemical, and growth characteristics, I-type was approved as a neuroblastoma stem cell due to its differentiation and malignant potential [8]. Furthermore, as described above, neuroblastoma is typical childhood cancer that may have many stem cells exhibiting ACD that were generated in the developmental stage [17].

Although this review presents the intrinsic factors of $A C D$, further studies are necessary for clarify the extrinsic factors of ACD such as the tumor microenvironment. For this purpose, the neuroblastoma culture system is advantageous in that it is possible to build a variety of extracellular environments in vitro.

Human neuroblastoma cultured cells are suitable model system for providing insight into the mechanisms underlying ACD. We hope that many ACD studies will employ cultured neuroblastoma cells.

Author Contributions: H.I. performed the literature review; H.I., Y.K. and A.N. wrote the manuscript; and H.I. submitted the manuscript to the journal. All authors have read and agreed to the published version of the manuscript.

Funding: This review article was financially supported by the Japan Society for the Promotion of Science (18K07223).

Data Availability Statement: Not applicable.

Conflicts of Interest: The authors declare that this research was conducted in the absence of any commercial or financial relationships that may be construed as a potential conflict of interest.

\section{References}

1. Brodeur, G.M. Neuroblastoma: Biological insights into a clinical enigma. Nat. Rev. Cancer 2003, 3, 203-216. [CrossRef]

2. Matthay, K.K.; Maris, J.M.; Schleiermacher, G.; Nakagawara, A.; Mackall, C.L.; Diller, L.; Weiss, W.A. Neuroblastoma. Nat. Rev. Dis. Primers 2016, 2, 16078. [CrossRef] [PubMed]

3. Nakagawara, A.; Li, Y.; Izumi, H.; Muramori, K.; Inada, H.; Nishi, M. Neuroblastoma. Jpn. J. Clin. Oncol. 2018, 48, $214-241$. [CrossRef] [PubMed]

4. Cotterman, R.; Knoepfler, P.S. N-Myc regulates expression of pluripotency genes in neuroblastoma including lif, klf2, klf4, and lin28b. PLoS ONE 2009, 4, e5799. [CrossRef] [PubMed]

5. Huang, M.; Weiss, W.A. Neuroblastoma and MYCN. Cold Spring Harb. Perspect. Med. 2013, 3, a014415. [CrossRef] [PubMed]

6. Zhang, J.T.; Weng, Z.H.; Tsang, K.S.; Tsang, L.L.; Chan, H.C.; Jiang, X.H. MycN Is Critical for the Maintenance of Human Embryonic Stem Cell-Derived Neural Crest Stem Cells. PLoS ONE 2016, 11, e0148062. [CrossRef]

7. Kerosuo, L.; Neppala, P.; Hsin, J.; Mohlin, S.; Vieceli, F.M.; Torok, Z.; Laine, A.; Westermarck, J.; Bronner, M.E. Enhanced expression of MycN/CIP2A drives neural crest toward a neural stem cell-like fate: Implications for priming of neuroblastoma. Proc. Natl. Acad. Sci. USA 2018, 115, E7351-E7360. [CrossRef] [PubMed]

8. Ross, R.A.; Spengler, B.A. Human neuroblastoma stem cells. Semin. Cancer Biol. 2007, 17, 241-247. [CrossRef]

9. Morrison, S.J.; Kimble, J. Asymmetric and symmetric stem-cell divisions in development and cancer. Nature 2006, 441, 1068-1074. [CrossRef]

10. Meacham, C.E.; Morrison, S.J. Tumour heterogeneity and cancer cell plasticity. Nature 2013, 501, 328-337. [CrossRef]

11. Caussinus, E.; Gonzalez, C. Induction of tumor growth by altered stem-cell asymmetric division in Drosophila melanogaster. Nat. Genet. 2005, 37, 1125-1129. [CrossRef]

12. Clevers, H. Stem cells, asymmetric division and cancer. Nat. Genet. 2005, 37, 1027-1028. [CrossRef] [PubMed]

13. Knoblich, J.A. Asymmetric cell division: Recent developments and their implications for tumour biology. Nat. Rev. Mol. Cell Biol. 2010, 11, 849-860. [CrossRef] [PubMed]

14. Izumi, H.; Kaneko, Y. Evidence of asymmetric cell division and centrosome inheritance in human neuroblastoma cells. Proc. Natl. Acad. Sci. USA 2012, 109, 18048-18053. [CrossRef] [PubMed] 
15. Izumi, H.; Kaneko, Y. Trim32 facilitates degradation of MYCN on spindle poles and induces asymmetric cell division in human neuroblastoma cells. Cancer Res. 2014. [CrossRef] [PubMed]

16. Izumi, H.; Kaneko, Y. Symmetry breaking in human neuroblastoma cells. Mol. Cell Oncol. 2014, 1, e968510. [CrossRef]

17. Izumi, H.; Kaneko, Y.; Nakagawara, A. The Role of MYCN in Symmetric vs. Asymmetric Cell Division of Human Neuroblastoma Cells. Front. Oncol. 2020, 10, 570815. [CrossRef] [PubMed]

18. Gonczy, P. Mechanisms of asymmetric cell division: Flies and worms pave the way. Nat. Rev. Mol. Cell Biol. 2008, 9, 355-366. [CrossRef]

19. Sawa, H. Control of cell polarity and asymmetric division in C. elegans. Curr. Top. Dev. Biol. 2012, 101, 55-76. [CrossRef]

20. Gonzalez, C. Spindle orientation, asymmetric division and tumour suppression in Drosophila stem cells. Nat. Rev. Genet. 2007, 8, 462-472. [CrossRef]

21. Yamashita, Y.M.; Mahowald, A.P.; Perlin, J.R.; Fuller, M.T. Asymmetric inheritance of mother versus daughter centrosome in stem cell division. Science 2007, 315, 518-521. [CrossRef]

22. Shinin, V.; Gayraud-Morel, B.; Gomes, D.; Tajbakhsh, S. Asymmetric division and cosegregation of template DNA strands in adult muscle satellite cells. Nat. Cell Biol. 2006, 8, 677-687. [CrossRef] [PubMed]

23. Lechler, T.; Fuchs, E. Asymmetric cell divisions promote stratification and differentiation of mammalian skin. Nature 2005, 437, 275-280. [CrossRef] [PubMed]

24. Quyn, A.J.; Appleton, P.L.; Carey, F.A.; Steele, R.J.; Barker, N.; Clevers, H.; Ridgway, R.A.; Sansom, O.J.; Nathke, I.S. Spindle orientation bias in gut epithelial stem cell compartments is lost in precancerous tissue. Cell Stem Cell 2010, 6, 175-181. [CrossRef] [PubMed]

25. Cicalese, A.; Bonizzi, G.; Pasi, C.E.; Faretta, M.; Ronzoni, S.; Giulini, B.; Brisken, C.; Minucci, S.; Di Fiore, P.P.; Pelicci, P.G. The tumor suppressor $\mathrm{p} 53$ regulates polarity of self-renewing divisions in mammary stem cells. Cell 2009, 138, 1083-1095. [CrossRef]

26. Wu, M.; Kwon, H.Y.; Rattis, F.; Blum, J.; Zhao, C.; Ashkenazi, R.; Jackson, T.L.; Gaiano, N.; Oliver, T.; Reya, T. Imaging hematopoietic precursor division in real time. Cell Stem Cell 2007, 1, 541-554. [CrossRef]

27. Costa, M.R.; Wen, G.; Lepier, A.; Schroeder, T.; Gotz, M. Par-complex proteins promote proliferative progenitor divisions in the developing mouse cerebral cortex. Development 2008, 135, 11-22. [CrossRef]

28. Wang, X.; Tsai, J.W.; Imai, J.H.; Lian, W.N.; Vallee, R.B.; Shi, S.H. Asymmetric centrosome inheritance maintains neural progenitors in the neocortex. Nature 2009, 461, 947-955. [CrossRef]

29. Matthay, K.K.; Villablanca, J.G.; Seeger, R.C.; Stram, D.O.; Harris, R.E.; Ramsay, N.K.; Swift, P.; Shimada, H.; Black, C.T.; Brodeur, G.M.; et al. Treatment of high-risk neuroblastoma with intensive chemotherapy, radiotherapy, autologous bone marrow transplantation, and 13-cis-retinoic acid. Children's Cancer Group. N. Engl. J. Med. 1999, 341, 1165-1173. [CrossRef]

30. Conacci-Sorrell, M.; McFerrin, L.; Eisenman, R.N. An overview of MYC and its interactome. Cold Spring Harb. Perspect. Med. 2014, 4, a014357. [CrossRef]

31. Knoepfler, P.S.; Cheng, P.F.; Eisenman, R.N. N-myc is essential during neurogenesis for the rapid expansion of progenitor cell populations and the inhibition of neuronal differentiation. Genes Dev. 2002, 16, 2699-2712. [CrossRef] [PubMed]

32. Giannini, G.; Cerignoli, F.; Mellone, M.; Massimi, I.; Ambrosi, C.; Rinaldi, C.; Dominici, C.; Frati, L.; Screpanti, I.; Gulino, A. High mobility group A1 is a molecular target for MYCN in human neuroblastoma. Cancer Res. 2005, 65, 8308-8316. [CrossRef] [PubMed]

33. Guo, Y.F.; Duan, J.J.; Wang, J.; Li, L.; Wang, D.; Liu, X.Z.; Yang, J.; Zhang, H.R.; Lv, J.; Yang, Y.J.; et al. Inhibition of the ALDH18A1-MYCN positive feedback loop attenuates MYCN-amplified neuroblastoma growth. Sci. Transl. Med. $2020,12$. [CrossRef]

34. Suenaga, Y.; Islam, S.M.; Alagu, J.; Kaneko, Y.; Kato, M.; Tanaka, Y.; Kawana, H.; Hossain, S.; Matsumoto, D.; Yamamoto, M.; et al. NCYM, a Cis-antisense gene of MYCN, encodes a de novo evolved protein that inhibits GSK3beta resulting in the stabilization of MYCN in human neuroblastomas. PLoS Genet 2014, 10, e1003996. [CrossRef]

35. Kaneko, Y.; Suenaga, Y.; Islam, S.M.; Matsumoto, D.; Nakamura, Y.; Ohira, M.; Yokoi, S.; Nakagawara, A. Functional interplay between MYCN, NCYM, and OCT4 promotes aggressiveness of human neuroblastomas. Cancer Sci. 2015, 106, 840-847. [CrossRef] [PubMed]

36. Puca, F.; Tosti, N.; Federico, A.; Kuzay, Y.; Pepe, A.; Morlando, S.; Savarese, T.; D'Alessio, F.; Colamaio, M.; Sarnataro, D.; et al. HMGA1 negatively regulates NUMB expression at transcriptional and post transcriptional level in glioblastoma stem cells. Cell Cycle 2019, 18, 1446-1457. [CrossRef]

37. Puca, F.; Colamaio, M.; Federico, A.; Gemei, M.; Tosti, N.; Bastos, A.U.; Del Vecchio, L.; Pece, S.; Battista, S.; Fusco, A. HMGA1 silencing restores normal stem cell characteristics in colon cancer stem cells by increasing p53 levels. Oncotarget 2014, 5, 3234-3245. [CrossRef]

38. Colaluca, I.N.; Tosoni, D.; Nuciforo, P.; Senic-Matuglia, F.; Galimberti, V.; Viale, G.; Pece, S.; Di Fiore, P.P. NUMB controls p53 tumour suppressor activity. Nature 2008, 451, 76-80. [CrossRef]

39. Betschinger, J.; Mechtler, K.; Knoblich, J.A. Asymmetric segregation of the tumor suppressor brat regulates self-renewal in Drosophila neural stem cells. Cell 2006, 124, 1241-1253. [CrossRef]

40. Schwamborn, J.C.; Berezikov, E.; Knoblich, J.A. The TRIM-NHL protein TRIM32 activates microRNAs and prevents self-renewal in mouse neural progenitors. Cell 2009, 136, 913-925. [CrossRef] 
41. Chen, C.; Yamashita, Y.M. Centrosome-centric view of asymmetric stem cell division. Open Biol. 2021, 11, 200314. [CrossRef] [PubMed]

42. Habib, S.J.; Chen, B.C.; Tsai, F.C.; Anastassiadis, K.; Meyer, T.; Betzig, E.; Nusse, R. A localized Wnt signal orients asymmetric stem cell division in vitro. Science 2013, 339, 1445-1448. [CrossRef] [PubMed]

43. Januschke, J.; Llamazares, S.; Reina, J.; Gonzalez, C. Drosophila neuroblasts retain the daughter centrosome. Nat. Commun. 2011, 2, 243. [CrossRef] [PubMed]

44. Salzmann, V.; Chen, C.; Chiang, C.Y.; Tiyaboonchai, A.; Mayer, M.; Yamashita, Y.M. Centrosome-dependent asymmetric inheritance of the midbody ring in Drosophila germline stem cell division. Mol. Biol. Cell 2014, 25, 267-275. [CrossRef] [PubMed] 